\title{
Improvement of financing system of technological development on Ukrainian agricultural machine- building enterprises
}

\author{
Nadiia P. Reznik \\ Doctor of economic sciences, professor \\ head of Department of Exchange \\ Activity and Trade \\ National university of life and \\ environmental science of Ukraine \\ Kyiv, Ukraine \\ https://orcid.org/0000-0001-9588-5929
}

\author{
Anna M. Slobodianyk* \\ $P h D$ (in Economics), \\ associate professor of the department \\ of Exchange Activity and Trade \\ National university of life and \\ environmental science of Ukraine \\ Kyiv, Ukraine \\ https://orcid.org/0000-0001-6437-0033 \\ Anna M. Ivanova \\ PhD in Economics, \\ Lecturer of department taxes and fiscal \\ policy \\ Ternopil National Economic University \\ Ternopil, Ukraine \\ https://orcid.org/0000-0002-6932-8800
}

\author{
Valentyna M. Panasiuk \\ $\mathrm{PhD}$ (in Economics), Associate \\ Professor, Department of Accounting \\ and Taxation of Entrpreneurship \\ Dean of the Faculty of Accounting and \\ Audit \\ Ternopil National Economic University \\ Ternopil, Ukraine \\ https://orcid.org/0000-0002-5133-6431
}

\begin{abstract}
The article is devoted to the problem of research of prospects of financing of research and design works at Ukrainian agricultural machine-building enterprises, which will provide acceleration of scientific and technological progress in science-intensive and perspective directions of state development. It is proved that for effective implementation of innovative activity of the enterprise, the system of management of its financing must be built taking into account the life cycle of innovations at the enterprise, the scale and organizational legal form of its management. The essence of financing of innovations in the enterprise is characterized, which is expedient to be defined as a complex of measures for providing innovations and innovative activity with financial resources through methods and forms, ways of financing, i.e. in accumulation Ltd. SPE "BILOTSERKIVMAZ" of a certain part of financial resources and its direction towards achievement of goals, the main among which is financing of investment and innovation processes in order to form and implement an innovative model of development. It is substantiated that the proposed innovation cluster as a new scientific and technological formation will contribute to technological re-equipment of industrial enterprises, development of innovative infrastructure of the region, development of industrial production, agrarian sector, improvement of socio-economic status in the region.
\end{abstract}

Keywords-financial support, research and technological development, budget financing, investment and innovation activity, innovation activity, informational and technological revolution, non-state funds.

\section{INTRODUCTION}

Mechanical engineering is a science-intensive industry, and in this regard, an important factor affecting its development is the level of scientific and technological progress. Scientific and technological progress contributes to the improvement of the technical armament of the enterprise, change of technologies, growth of mechanization and automation of production. Many large industrial enterprises include research institutes and testing facilities. These units are engaged in basic and applied research, perform research and technological development and experimental work, thereby enhancing the country's scientific potential. Establishing an effective mechanism for financing and budget support for the investment and innovation sector remains a relevant issue for the economy of the enterprise. Analysis and evaluation of foreign experience of financial support of innovative projects and programs is a leading prerequisite for building an effective model of economic development Ltd. SPE «BILOTSERKIVMAZ». Financing of scientific activity at the enterprise is carried out mainly at the expense of the enterprise's own funds or at the expense of state budget funds, which are allocated within the framework of longterm targeted programs or on the basis of securing contracts for the execution of government orders. In today's context, it becomes an unbearable burden on the state budget, which results in irregular funding and the decline of research in some areas.

This problem was reflected in the writings of domestic scientists - V. Heyts, T. Bogolib, M. Zgurovsky, V. Kremen, S. Nikolayenko, O. Levchyshina, I.Kaleniuk, L. Fedulova. Among foreign authors it should be noted: R. Anthony, K. Freeman, P. Boyer, B. Goden, B. Twiss, P. White, J. Martino, J. Schumpeter, F. Mahlap, D. Novik. However, the issue of financial support for research and development work at the enterprise are researched poorly.

\section{THE PURPOSE OF THE RESEARCH}

Is to study the prospects of financing research and technological development at Ukrainian agricultural machine-building enterprises and to identify strategic approaches and directions for improving the financing of 
research and technological development in the light of foreign experience.

\section{RESULTS}

In recent years, there has been a significant decrease in the funding of research and technological development (hereinafter RTD) in Ukraine, accompanied by changes and reductions in revenues, as well as the funding of mainly basic research. In the current conditions for the state, RTD funding at all stages becomes an unbearable burden on the state budget, which results in irregular funding and the decline of research in certain fields. Meanwhile, the experience of developed countries shows that even in times of economic crisis, it is possible to attract funds from both state and non-state structures for research. In most foreign countries, a combination of direct (budget financing) and indirect (tax, amortization privileges) methods of regulating the investment-innovation activity of economic entities is usually used. The realities of development of the Ukrainian economy should require not blind copying of instruments of organization and financing of investment and innovation policy of a certain foreign country, but combination of the most effective mechanisms of fiscal regulation and stimulation of scientific and technological progress.

In the context of Ukraine's strategic orientation to an innovative image of development, the adaptation of enterprises to the new conditions of a market economy and its active reforming are closely linked to innovation as a driving force for economic growth. Strategic approach from everyday activities is characterized by the desire to achieve the goals and foresight, submission to today's goal of the ideal of self-development, selection of the most optimal scenarios and the ability to move from one scenario to the next in the most favorable from the point of view of development. In the face of constant risk, a strategic outlook on innovation allows you to respond to change in a timely manner, to launch the very technology that will deliver a major advantage and bring a market leading edge. It is the strategic approach to entrepreneurship that today transforms innovation into an activity and a social moment of particular importance [1].

Problems of economic growth, increasing competitiveness in the conditions of information and technological revolution can be solved with the help of effective strategies of innovative development. It is the consistent innovation strategy that has led to high quality of life, national security, environmental protection and high technical level of the developed countries of the world [2]. Therefore, it is not a one-time use of innovations to achieve instant benefits, but a continuous, accountable strategic innovation development that shapes methods and tools for managing innovation and will allow the innovation to be subordinated to the general goals, transforming the intensive implementation of the innovation process in the moment of economic growth.

Thus, in terms of scientific and technical activities in Ukraine, a system of direct financial support measures is provided. For comparison, similar tools are used in international practice to stimulate the financing of science and innovation: government subsidies and grants, public procurement and grants.

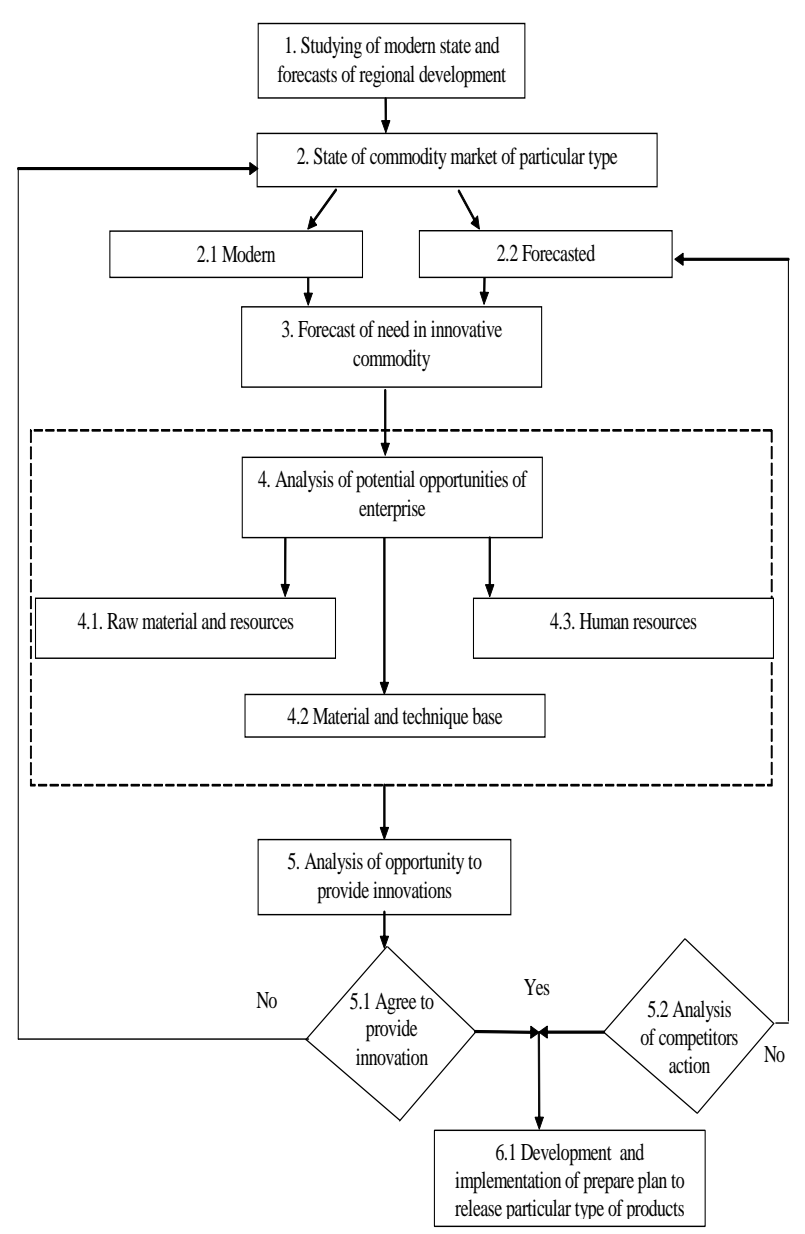

Source: development of Ltd. SPE «BILOTSERKIVMAZ»

Fig. 1. Marketing concept of activity development of Ltd. SPE «BILOTSERKIVMAZ» in the production of innovative products

However, these tools are more effective in developed countries because:

1. complies with the legislation in the field of financing of scientific and technical activities;

2. State targeted programs are funded in a timely and full manner;

3. substantiated priorities for the development of scientific activity;

4. non-state funds are being attracted to the scientific sphere to a greater extent.

Financing of RTD in Ltd. SPE "BILOTSERKIVMAZ" for $2017-2018$ is covered for $100 \%$ at the expense of the enterprise's own funds. According to Article 138 of the Tax Code of Ukraine, the list of expenditures on RTD includes [3]:

- depreciation on fixed assets and intangible assets (except for buildings and structures) used at the enterprise in the course of scientific research and development work;

- the cost of remuneration of personnel involved in carrying out research and development;

- material costs directly related to the conduct of research and development work; 
- other expenses related to the carrying out of scientific researches and RTD;

- the cost of works under contracts for the implementation of scientific and research works, contracts for the implementation of RTD in the event that the taxpayer acts as the customer of scientific research and research and technological development.

The expenses of enterprises on RTD are recognized for tax purposes regardless of the results obtained [4].

As in Ukraine there is a discrepancy between the existing innovative potential and the financial and economic possibilities of its realization, in Ltd. SPE «BILOTSERKIVMAZ» has formed its own concept of development of an innovative type enterprise.

The need to develop a mechanism for strategic innovative development of enterprises requires clarification of the substantive component of the concept of "innovation strategy" in the current economic environment, as well as the development of new approaches to the processes of its formation and choice.

Remaining Profit Ltd. SPE «BILOTSERKIVMAZ» is used by them independently and is directed to further development of business activity. No authorities, including the state, have the right to interfere in the process of using the enterprise's net profit. Market conditions determine the priority directions of own profit. The development of competition causes the need to expand production, improve it, meet the material and social needs of labor collectives.

TABLE I. PRODUCTION SCHEME OF NEW TECHNOLOGY BY SUBDIVISIONS JULY - AUGUST, 2017 STEP 1

\begin{tabular}{|c|c|c|c|c|c|c|}
\hline \multicolumn{7}{|c|}{ Stage 1 - workshop №124 } \\
\hline \multicolumn{5}{|c|}{ Plan of production } & \multicolumn{2}{|c|}{ Price } \\
\hline & \multicolumn{2}{|c|}{$\begin{array}{c}\text { Serial } \\
\text { technology }\end{array}$} & \multicolumn{2}{|c|}{$\begin{array}{c}\text { New } \\
\text { technology }\end{array}$} & & \\
\hline & VII & VIII & VII & VIII & first & second \\
\hline AG-2,4 & & 50 & & & & \\
\hline $\mathrm{AG}-3,3$ & 15 & & & & & \\
\hline AGP-2,4 & 10 & 10 & & & & \\
\hline AGP-3,0 & 8 & & & & & \\
\hline UDA-2,4 & 5 & 5 & & & & \\
\hline UDA-3,8 & 10 & & & & & \\
\hline UDA-4,5 & 20 & & & & & \\
\hline $\mathrm{PN}-2,0$ & 35 & 15 & & & & \\
\hline BPV-9 & & & & 8 & & \\
\hline BPV-21 & & & 4 & & 231770 & 463540 \\
\hline UGP-6,0 & & 3 & & & & \\
\hline ROS-2,0 & & 35 & & & & \\
\hline KPF-2,4 & & & & 10 & & \\
\hline $\begin{array}{l}\text { NITROMASTER } \\
9-45\end{array}$ & & & 2 & 3 & & \\
\hline KP-8 & & & 4 & & & \\
\hline KP-12 & & & 4 & & & \\
\hline DICH-3,1 & & & & & & \\
\hline TOW TRUCK & & & & 10 & 55000 & 137500 \\
\hline LUG-14 & & & & 10 & & \\
\hline
\end{tabular}

Accordingly, on receipt, net income of Ltd. SPE «BILOTSERKIVMAZ» is directed to: financing of RTD, as well as works on creation, development and implementation of equipment (Table 1). Also directed to improve technology and organization of production, to upgrade equipment, improve product quality; technical reequipment, reconstruction of existing production.

TABLE II. PRODUCTION SCHEME OF NEW TECHNOLOGY BY SUBDIVISIONS JULY - AUGUST, 2017 STEP 2

\begin{tabular}{|l|c|c|c|}
\hline \multicolumn{3}{|c|}{$\begin{array}{c}\text { Stage 2 - Experimental department } \\
\text { Plan of production } \\
\text { new technology }\end{array}$} \\
\hline \multicolumn{3}{|c|}{ July } & \multicolumn{2}{c|}{ August } \\
\hline DICH-3,8 & & \multicolumn{2}{c|}{} \\
\hline DICH-4,5 & & & 1 \\
\hline UGP-10 & & & \\
\hline UGP-12,5 & 1 & 64800 & \\
\hline Pickupper to KPF-2,4 & \multicolumn{3}{|c|}{ postponded to 2018 } \\
\hline Spreader RMDU-2100 & \multicolumn{3}{|c|}{ decision wasn't accepted } \\
\hline Auto feederAPP-6,0 & \multicolumn{3}{|c|}{ Source: data of Ltd.SPE «BILOTSERKIVMAZ» } \\
\hline PeererRV-3,0 &
\end{tabular}

Net income is a source of replenishment of own working capital. In addition, it is directed to the payment of interest on loans received to fill the lack of working capital, to purchase fixed assets, as well as the payment of interest on overdue and deferred loans.

TABLE III. PRODUCTION SCHEME OF NEW TECHNOLOGY BY SUBDIVISIONS JULY - AUGUST, 2017 STEP 3

\begin{tabular}{|l|c|c|c|}
\hline \multicolumn{4}{|c|}{ Stage 3 - Department №5 Plan of production new technology } \\
\hline & July & August & Total \\
\hline Container 5,5 & 1 & 1 & \\
\hline Container 7,5 & 2 & 1 & \\
\hline Container 35 & & 2 & \\
\hline Cart under conteiner 5,5 & 1 & 1 & \\
\hline Cart under conteiner 7,5 & 3 & & \\
\hline Grain transport semitrailer & & 2 & \\
\hline real volume 70 & & 1 & \\
\hline real volume 50 & & & 140000 \\
\hline Cab & \multicolumn{5}{|l|}{} \\
\hline Total price &
\end{tabular}

Source: data of Ltd.SPE «BILOTSERKIVMAZ»

As we can see from the table 1,2 and 3, for the period from July to August, 2017, a total of 52 units of new equipment were manufactured in the departments of the enterprise. Total cost is 1454210,00 million UAH, for $28 \%$ more employees were employed than usually. In total for 2017 in Ltd. SPE «BILOTSERKIVMAZ» 538 units of new technologies were manufactured by departments which priceis 15045480,384 billion UAH. Compared to the previous years, it means a steady upward trend.

In our opinion, for effective implementation of innovative activity of the enterprise, the system of managing its financing must be built taking into account the life cycle of innovation in the enterprise, the scale and legal form of its management. According to theoretical and practical studies of the processes of managing the financing of innovation activity, it is advisable to combine and use different sources of financial support for innovation activity at different stages of the innovation life cycle [5].

As global and domestic experience in managing financial support for innovation shows, classical investors typically refrain from financing because of the high level of 
alternative costs of such investments, at the stage of basic research. Because of this, basic research is mostly carried out at the expense of the state budget on an irrevocable basis and programs for solving the most important scientific and technical problems.

Applied research is financed by the budget (government research programs or competitive base) and customers [6]. Borrowed money isn't used as it may deplete the innovators' own resources and revenue isn't expected in the immediate future. As the result of applied research is unpredictable, the negative result is possible. It is from this stage the possibility of risk to lost investment appears [7].

At the stage of RTD and experimental work, analyzing the activities of the leading world companies of innovation management and comparing them with Ltd. SPE «BILOTSERKIVMAZ», it can be concluded that the innovative management of the company is under development. The company is constantly working on the introduction of foreign experience in financing RTD, regardless of the situation in the country, Ltd. SPE "BILOTSERKIVMAZ" works for $100 \%$ at the expense of its own capital, following the experience of the USA, Japan and Germany on the depreciation policy.

Organization of RTD in Ltd. SPE BILOTSERKIVMAZ should be implemented with using the principle of advanced mastery of innovations. Important characteristics are the intensity of the mastering process and the level of development, but not the speed or duration of innovations.

On the development stage (this is the first stage of financing by Ltd. SPE «BILOTSERKIVMAZ») venture capital and capital of "business-angels" are involved before use of budget financing and own funds. Moreover, the capital of "business-angels" many times exceed the capital of the venture funds and, by some estimations, informal investors in the world provide for about $90 \%$ of total financing.

In the following stages of the innovation life cycle, such as development of production, consumption, commercialization of innovations and aging, own and borrowed capitals are involved in financing: securities issue and bank loans, partial government support, which requires defining the optimal correlation between these sources [8].

The enterprise carries out all kinds of RTD independently. Only after the prototype is made, it is sent to the Ukrainian Scientific Research Institute for the forecasting and testing of machinery and technologies for agricultural production named after L. Pohorilyy.

In our opinion, it is expedient to define financing of innovations at the enterprise as a complex of measures for providing innovations and innovative activity with financial resources through methods and forms, ways of financing. Its essence lies in the accumulation of Ltd. SPE "BILOTSERKIVMAZ" of a certain part of financial resources and its direction towards achievement of goals, the main among which is financing of investment and innovation processes in order to form and implement an innovative model of development.

We offer to create an innovation cluster as a new scientific and technological formation which appear as the result of the integration of related economic entities in the innovation and restoration spheres of the region, has great potential for accelerating the innovative development and technological renewal of fixed assets of the enterprises in the region.

Accelerating the processes of innovative development of the economy in the region, catalyzed by the innovation cluster, is achieved by consolidating the potential of various scientific institutions, innovation structures, banking and other financial and credit institutions that have close organizational and economic connections [9]. Clusters, thanks to the horizontal connections of its participants, who concentrate their efforts in certain areas of activity, have the opportunity to support their partners' initiative, facilitate creative process, generate new ideas, know-how, inventions that accelerate the processes of innovative transformation [10].

The concept of developing innovation clusters is based on the interconnections and interdependencies of innovation and investment institutions, technologically advanced and innovation-oriented enterprises and institutions, integrated into a network structure, the activities of which may be coordinated by a specific governing body.

Clusters allow businesses to respond more flexibly to changing business conditions. Firms relationships make the cluster members stronger than those working individually. Focusing on market needs, which is the main factor in defining the overall enterprise strategy, and ensuring that the strategy of each individual production is consistent with the overall strategy for the development of the innovation cluster.

Co-operation and cooperation are the impetus for finding new, perfect ways of working, focusing on innovation, attracting internal and external investment. Innovation clusters create a new product or service through the efforts of multiple firms or research institutes to accelerate its spreading across the business network. The scheme of the innovation cluster is shown in Figure 2.

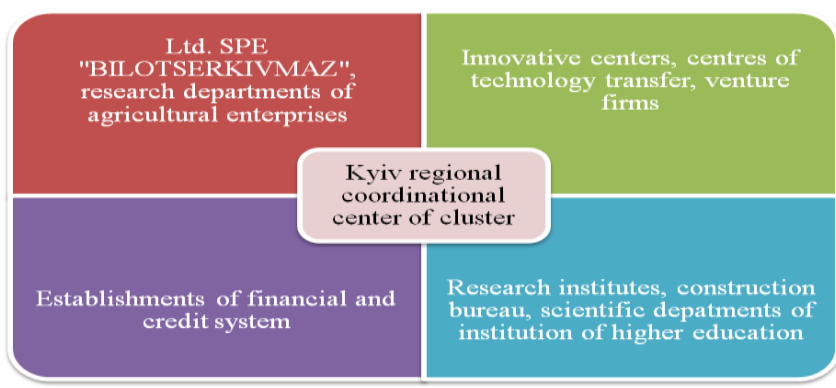

Source: author's collaboration.

Fig. 2. Scheme of innovative cluster in Kyiv Region with participation of Ltd. SPE «BILOTSERKIVMAZ»

The innovation cluster in Kyiv Region with participation of Ltd. SPE «BILOTSERKIVMAZ», as an association of different organizations (industrial companies, research centers, scientific establishments, government bodies, trade unions, public organizations), allows to take advantage of internal firm's coordination and market mechanism for faster and more efficient development of new knowledge. In this case, innovations are spread across the network of 
interconnections in the common economic space, facilitating a combination of production factors.

An innovation cluster is created on the basis of existing and active enterprises and organizations through reorganization and new structuring. The basic principle of formation of an innovation cluster is the choice of priority directions of scientific, research and technological development of the economy on the territory, taking into account the scientific and innovative potential of the objects involved in solving tasks. The cluster-based regional model of innovative system allows to integrate the science and institution of higher education with industry.

The coordinating council for innovation development has reliable information on the activities of enterprises, markets and labor resources, which provides high-quality strategic planning, both at the level of the authorities and at the level of enterprises. The cluster members combine its resources and those of financial institutions to create new products, achieve greater economic efficiency and gain access to new technologies and new markets.

\section{CONCLUSIONS}

Implementation of the innovation cluster in the Kiev region with the participation of Ltd. SPE "BILOTSERKIVMAZ" as a tool for implementing the strategy of increasing the innovative potential of the region will provide increased investment in the development of the region's economy, will allow to attract resources to the prospective activities of the cluster with inefficient competitiveness, will open new and will expand market shares, will accelerate the pace of development and innovation in Kyiv and the region in general and in agricultural engineering in particular, will reduce unemployment in the region and also will solve other social problems of the region. The developed by us model and adopted innovation and investment priorities of the region development based on the innovation cluster will contribute to the technological re-equipment of Ltd. SPE "BILOTSERKIVMAZ" and other production enterprises within the cluster, the development of innovative infrastructure in the Kyiv region, the development of industrial production of region, the agrarian sector, and an improvement of social and economic position in the region.

\section{REFERENCES}

[1] O. Pavlova, "Competitive Ability of Ukrainian Agricultural MachineBuilding Enterprises In the World market", Editorial board, vol.17, no. 11, pp. 11-15, 2016. [in Ukrainian]

[2] V. Yakubiv, I. Boryshkevych and I. Piatnychuk, "Strategic analysis of development of agricultural enterprises of Ivano-Frankivsk region", The actual problems of regional economy development, vol. 2, no. 14, pp.16-24, 2018. [in Ukrainian]

[3] Tax Code of Ukraine. [Online]. Available: https://zakon.rada.gov.ua/laws/show/2755-17. Accessed on: August 13, 2019. [in Ukrainian]

[4] O. Pyrog and K. Stelmakh, "Operation and modernisation of fixed assets at machine-building enterprises", Economics, entrepreneurship, management, vol. 3, no. 1, pp.41-50, 2016. [in Ukrainian]

[5] O. Kryvoruchkina, V. Hmyria and M. Tepliuk, "Financial and economic aspects to ensure growth of capitalization in the activity of Ukraine's machine building enterprises", Financial and credit activity: problems of theory and practice, vol. 4 , no. 27 , pp. 370-380, 2018. [in Ukrainian]

[6] V. Ulanchuk, et al. "Investment needs assessment of Ukrainian agricultural enterprises", Investment Management and Financial Innovations, no. 14. pp. 181-190, 2017. [in Ukrainian]

[7] L. Naymova, O. Mityay, and A. Galitsky, "Development of the innovative enterprises of the agrarian production in the current economic system of Ukraine", Scientific bulletin Polesie, no. 3 (7), pp. 124-129, 2016. [in Ukrainian]

[8] O. Kuzmin, O. Melnyk, N. Shpak and O. Muk, "The concept of creation and use of the polycriterial diagnostics systems of enterprise activity", Econtechmod: An International Quarterly Journal on Economics of Technology and Modelling Processes, no.1, pp.23-28, 2012. [in Ukrainian]

[9] Mogilevska O. and Slobodyanik A., "Economic essence of investment attractiveness of industrial holding". Global and National Problems of Economy, no. 21, pp. 335-338, 2018. [Online]. available at: http://global-national.in.ua/issue-21-2018/29-vipusk-21-lyutij2018-r/3780-mogilevska-o-yu-slobodyanik-a-m-ekonomichna-sutnistinvestitsijnoji-privablivosti-promislovogo-kholdingu Accessed on: 26 Aug 2019. [in Ukrainian]

[10] O. Chukurna, V. Nitsenko, V. Kralia, Y. Sahachko, M. Morkunas and A. Volkov, "Modelling and managing the effect of transferring the dynamics of exchange rates on prices of machine-building enterprises in IJkraine". Polish Iournal of Management Studies vol 19. no 1 , pp. $117-129,2019 . \quad$ [in Ukrainian].• 